\title{
CYP2C8*4 Allele
}

National Cancer Institute

\section{Source}

National Cancer Institute. CYP2C8*4 Allele. NCI Thesaurus. Code C46032.

Human CYP2C8*4 allele is located in the vicinity of $10 \mathrm{q} 23.33$ and is approximately $33 \mathrm{~kb}$ in length. This allele, a variant form of the CYP2C8 wild-type allele, encodes cytochrome P450 2C8*4 protein. The CYP2C8*4 allele exhibits a SNP (c.792C>G) in exon 5 that results in an I264M coding change. However, this alteration in protein sequence has no significant effect on the enzymatic activity of the cytochrome P450 2C8*4 protein. 